\title{
Chemical Analysis of N, P, K, in Crop Land Area of Chitrakoot Region Satna (M.P.), India
}

\author{
Arvind Prasad Dwivedi
}

Lecturer, Department of Chemistry, Govt. Sanjya Gandhi Smrati Auto P.G.College Sidhi M.P.,India.

\begin{abstract}
The Chitrakoot region is included in the District Chitrakoot of Uttar Pradesh and the District Satna of Madhya Pradesh. Chitrakoot Parvat Mala includes Kamad Giri, Hanumaan Dhara, Janki Kund, Lakshman pahari, and Devangana famous Religious Mountains. Soils of Chitrakoot region are following types- (1) Light black (2) Sandy loam soil. Geographical information of Chitrakoot district Satna in located at $24^{\circ} 48^{\prime}$ to $25^{\circ} 12^{\prime} \mathrm{N}$, and longitude at $80^{\circ} 58^{\prime}$ to $81^{\circ} 34^{\prime} \mathrm{E}$ distance covered by district from east to west is $62 \mathrm{~km}$ and north to south is $57.5 \mathrm{~km}$. Temperature, $\mathrm{pH}$, Moisture Contents, $N, P$ and $K$ were analyzed in the soil samples during the sampling periods. Various soil quality parameters were analyzed by using standard procedures. The readings were taken with the help of Spectrophotometer. All the Soil samples were analyzed parameters like pH-(7.2 to 9.0), Temperature-(26 to $\left.28^{\circ} \mathrm{C}\right)$, Moisture content-(1.06 to $\left.3.25 \%\right), \mathrm{N}-(4.30$ to $34.13 \mathrm{mg} / \mathrm{kg}), \quad \mathrm{P}-(0.28$ to $3.07 \mathrm{mg} / \mathrm{kg})$, and $\mathrm{K}-(27$ to $56 \mathrm{mg} / \mathrm{kg})$, are in normal range. These studies give information about nature of soil, present nutrient in soil; according to this information farmer arrange the amount fertilizers and nutrients needed to soil for increase the crop production.
\end{abstract}

Keywords: Soil Quality, N, P, K, Crop Land Area, Chitrakoot Region, Satna Distrist

\section{INTRODUCTION}

Chitrakoot is a town and a nagar panchayat in Satna district in the state of Madhya Pradesh, India. Geographical information of Chitrakoot district Satna in located at $24^{0} 48^{\prime}$ to $25^{\circ} 12^{\prime} \mathrm{N}$, and longitude at $80^{\circ} 58^{\prime}$ to $81^{0} 34^{\prime} \mathrm{E}$ distance covered by district from east to west is $62 \mathrm{~km}$ and north to south is 57.5 $\mathrm{km}$. The town lies in the historical Chitrakoot region; it attracts crowds throughout the year including above occasions and for Free Eye Hospital Camps. Noted 'Ayurvedic' and 'Yoga' centres like 'Arogyadham' are located in Chitrakoot. Chitrakoot means the 'Hill of many wonders'. Chitrakoot falls in the northern Vindhya Range of mountains spread over the states of Uttar Pradesh and Madhya Pradesh. The Chitrakoot region is included in the District Chitrakoot of Uttar Pradesh and the District Satna of Madhya Pradesh. Chitrakoot Parvat Mala includes Kamad Giri, Hanumaan Dhara, Janki Kund, Lakshman pahari, and Devangana famous Religious Mountains. Soils of Chitrakoot region are following types- (1) Light black (2) Sandy loam soil.

The light black colour is attributed to the presence of tataniferous magnetite compound of iron and aluminium accumulated human and colloidal hydrate, double iron and aluminium silicate. In general these soils are rich in iron, lime, calcium, potash, aluminium and magnesium carbonate, but poor in nitrogen, phosphorus and organic matter. Light black soil it is thickness range between $30 \mathrm{~cm}$. to 100 $\mathrm{cm}$. It covers a corger area in Chitrakoot region of Madhya Pradesh. Loam is soil composed mostly of sand and silt and a smaller amount of clay (about 40\% sand, 40\%silt, 20\%clay). Loam is considered ideal for gardening and agricultural used. A soil dominated by one or two of the three particle size group can behave like loam if it has a strong granular structure, Promoted by a high content of organic matter of loam. Sandy soil increases water retention capacity and crop productivity ${ }^{[1]}$. Sandy soil increases crop yield and also reduces hydrophobicity by addition of clay content ${ }^{[2]}$. Soil is a complex natural medium and intensive soil physico-chemical testing is required to understand the behaviour of each soil type. Physiochemical characteristics of different soils vary in space and time due to variations in topography, climate, physical weathering processes, vegetation cover, microbial activities, and several other biotic and abiotic variables ${ }^{[3]}$. The properties of dry soil along with its type have a great importance in agriculture ${ }^{[4]}$.Different variety of soil contains different properties, which support the organism of soil, which maintain fertility. In soil management practice, variety of 
soil mixed so that all-important constitute and organism of all soil mixed and create a symbiotic relation to each and their sheltering plants and improve the soil quality and productivity ${ }^{[5]}$. The aim of this study was to determine the physicochemical parameters of soil that not only responsible for soil diversity of Chitrakoot but also affect the microbiological community and vegetation ${ }^{[6]}$. Soil types are a major factor in determining what types of plants will grow in a certain area as plants use inorganic elements from the soil such as nitrogen, potassium and phosphorus ${ }^{[7]}$.Most of the farmers are using excessive chemical fertilizers and the too much dose of such fertilizers in few soils has rendered high values of $\mathrm{P}$ and $\mathrm{K}$. The retention of $\mathrm{K}$ could also be due the clay minerals formed by chemical weathering of basalts which is the parent material for the soil ${ }^{[7]}$.Soil formation is a constructive as well as destructive process. Destructive process predominates the physical and chemical breaking down of materials, plants and animal structures, which result in the partial loss of more soluble and volatile products. Constructive forces develop new chemical compounds, both mineral and organic that provides new distribution or association characteristics, structural properties as well as chemical compositions. These factors influence the plant growth in the soil ${ }^{[8]}$.Soil texture is one of the most important soil properties governing most of the physical, chemical and hydrological properties of soils. Variability in soil texture may contribute to the variation in nutrient storage and availability, water retention and transport and binding and stability of soil aggregates. It can directly or indirectly influence many other soil functions and soil threats such as soil erosion ${ }^{[9]}$.

\section{Material AND Methods}

\subsection{Sample Collection}

The N, P, K, analysis of soil during month of March 2014. The sampling stations were chosen at different site of the study area. For testing the soil sample were collected in different sterile plastic container cans from each station. After collection of the sample the containers were tightly capped and were immediately transported to the laboratory to avoid any unpredictable changes in the physiochemical characteristics. Sample should be collected in clean and dry containers, and container should be rinsed thoroughly before collection of sample. Stopper the container after collections of the sample. Temperature, $\mathrm{pH}$, Moisture Contents, $\mathrm{N}, \mathrm{P}$ and $\mathrm{K}$ were analyzed in the soil samples during the sampling periods. Various soil quality parameters were analyzed by using standard procedures ${ }^{[10-}$

13]. The readings were taken with the help of Digital Spectrophotometer.

The sampling locations are presented in table- 1

Table1. List of sampling locations

\begin{tabular}{|c|c|c|c|c|}
\hline S.No. & $\begin{array}{l}\text { Depth } \\
\text { In cm }\end{array}$ & $\begin{array}{c}\text { Temperature } \\
{ }^{0} \mathrm{C}\end{array}$ & $\begin{array}{c}\text { Sampling locations } \\
\text { with code }\end{array}$ & $\begin{array}{c}\text { Description of } \\
\text { Sampling location }\end{array}$ \\
\hline 1. & $15 \mathrm{~cm}$ & 27 & Rajolla Farm (C1) & Rajolla farm of MGCGV \\
\hline 2. & $15 \mathrm{~cm}$ & 28 & Rajolla R.T.O (C2) & Behind Rajolla R.T.O. \\
\hline 3. & $15 \mathrm{~cm}$ & 26 & Rajolla Village (C3) & End Site of the Village \\
\hline 4. & $15 \mathrm{~cm}$ & 26 & Babupur $\quad(\mathrm{C} 4)$ & Semaria Mod \\
\hline 5. & $15 \mathrm{~cm}$ & 27 & Babupur & Near Kusdh Sewa Sadan \\
\hline 6. & $15 \mathrm{~cm}$ & 28 & Babupur & End Site of the Village \\
\hline 7. & $15 \mathrm{~cm}$ & 26 & $\begin{array}{l}\text { Patthra } \\
\text { (C7) }\end{array}$ & Godavari mod \\
\hline 8. & $15 \mathrm{~cm}$ & 28 & $\begin{array}{l}\text { Paldev } \\
\text { (C8) }\end{array}$ & Starting Border of the Village \\
\hline 9. & $15 \mathrm{~cm}$ & 26 & Manhai & Near Naala of Village \\
\hline 10. & $15 \mathrm{~cm}$ & 26 & Manhai & End Site of the Village \\
\hline
\end{tabular}

\section{RESUlts AND DiscuSSION}

In the present study ten soil samples were collected from Chitrakoot region of satna district. Various sampling station are chosen in the study area like Rajjola farm, Babupur, Patthra, Paldev, Manhai, etc. all the parameters were characterize and interpritate. Soil samples were analysed some physicochemical parameter like $\mathrm{pH}$, Temperature, Moisture Contents, N, P, K. and all the results are presented in Table-2 with Compared to SQGL Value. 
Chemical Analysis of N, P, K, in Crop Land Area of Chitrakoot Region Satna (M.P.), India

Table2. Physico-chemical characteristic of Soil collected from Crop land area of Chitrakoot Region

\begin{tabular}{|c|l|l|l|l|l|l|}
\hline $\begin{array}{l}\text { Parameters } \\
\text { Sample }\end{array}$ & $\mathbf{p H}$ & Temp. $^{\mathbf{0}} \mathbf{C}$ & $\begin{array}{l}\text { Moisture } \\
\mathbf{C o n t e n t s} \\
\mathbf{\%}\end{array}$ & $\begin{array}{l}\mathbf{N} \\
\mathbf{m g} / \mathbf{k g}\end{array}$ & $\begin{array}{l}\mathbf{P} \\
\mathbf{m g} / \mathbf{k g}\end{array}$ & $\begin{array}{l}\mathbf{K} \\
\mathbf{m g} / \mathbf{k g}\end{array}$ \\
\hline $\mathrm{C}_{1}$ & 9.0 & 27 & 3.12 & 9.41 & 0.60 & 56 \\
\hline $\mathrm{C}_{2}$ & 8.8 & 28 & 1.31 & 19.16 & 0.82 & 49 \\
\hline $\mathrm{C}_{3}$ & 8.2 & 26 & 1.46 & 6.29 & 0.28 & 42 \\
\hline $\mathrm{C}_{4}$ & 8.6 & 26 & 2.24 & 34.13 & 0.79 & 46 \\
\hline $\mathrm{C}_{5}$ & 7.3 & 27 & 1.06 & 8.56 & 1.14 & 32 \\
\hline $\mathrm{C}_{6}$ & 7.7 & 28 & 3.25 & 22.47 & 3.07 & 38 \\
\hline $\mathrm{C}_{7}$ & 7.2 & 26 & 1.13 & 4.30 & 0.35 & 27 \\
\hline $\mathrm{C}_{8}$ & 7.5 & 28 & 2.17 & 23.16 & 0.47 & 34 \\
\hline $\mathrm{C}_{9}$ & 8.6 & 26 & 2.06 & 29.0 & 0.38 & 48 \\
\hline $\mathrm{C}_{10}$ & 8.0 & 26 & 2.55 & 25.30 & 0.96 & 41 \\
\hline Means & 8.09 & 26.8 & 2.035 & 18.171 & 0.886 & 41.3 \\
\hline S.D. & 0.648 & 0.918 & 0.789 & 10.380 & 0.817 & 8.807 \\
\hline C.V. & 8.009 & 3.425 & 38.771 & 57.123 & 92.212 & 21.324 \\
\hline
\end{tabular}

The Temperature is basically an important factor for its effect on chemical and biological reaction in soil. Minimum $26^{\circ} \mathrm{C}$ and Maximum $28^{\circ} \mathrm{C}$ temperature were found in the crop land soil samples of Chitrakoot region. Temperature results of the all samples are given in table- 2 and shown in fig. 1 .

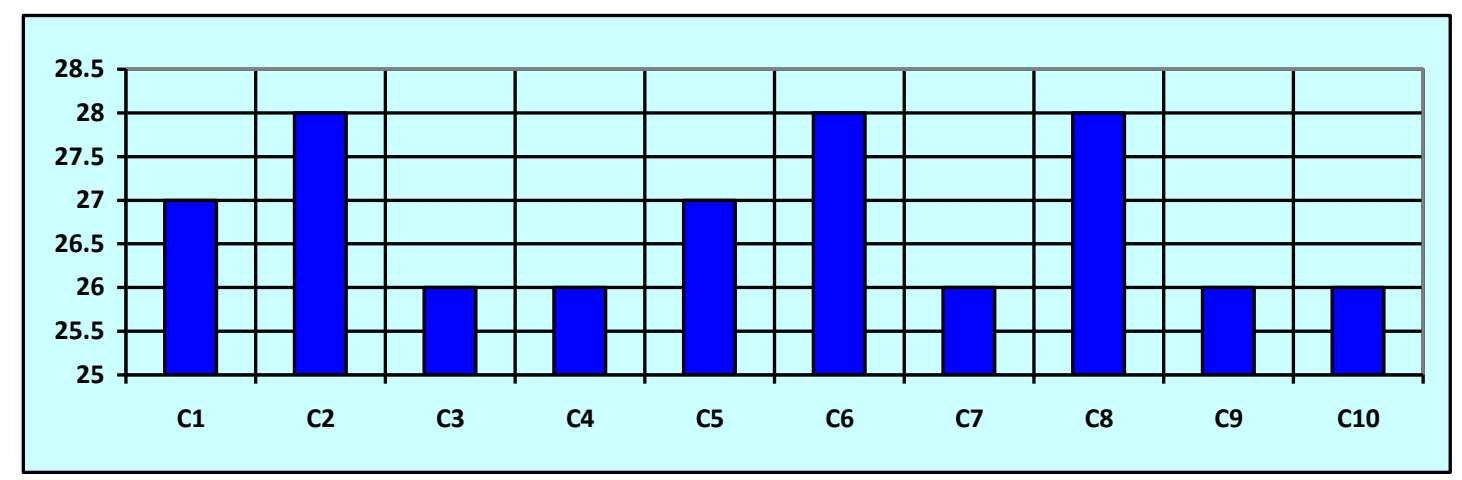

Fig1. Graphical representation of the temperature

\section{1.pH}

The hydrogen ion concentration is the indicator of acidity and alkalinity of any aqueous system. In the present study the sample $\mathrm{C} 7$ showed 7.2 of $\mathrm{pH}$ whereas sample $\mathrm{C} 1$ showed high percentage of $\mathrm{pH} 9.0$. $\mathrm{pH}$ results of the all samples are given in table-2 and shown in fig.2.

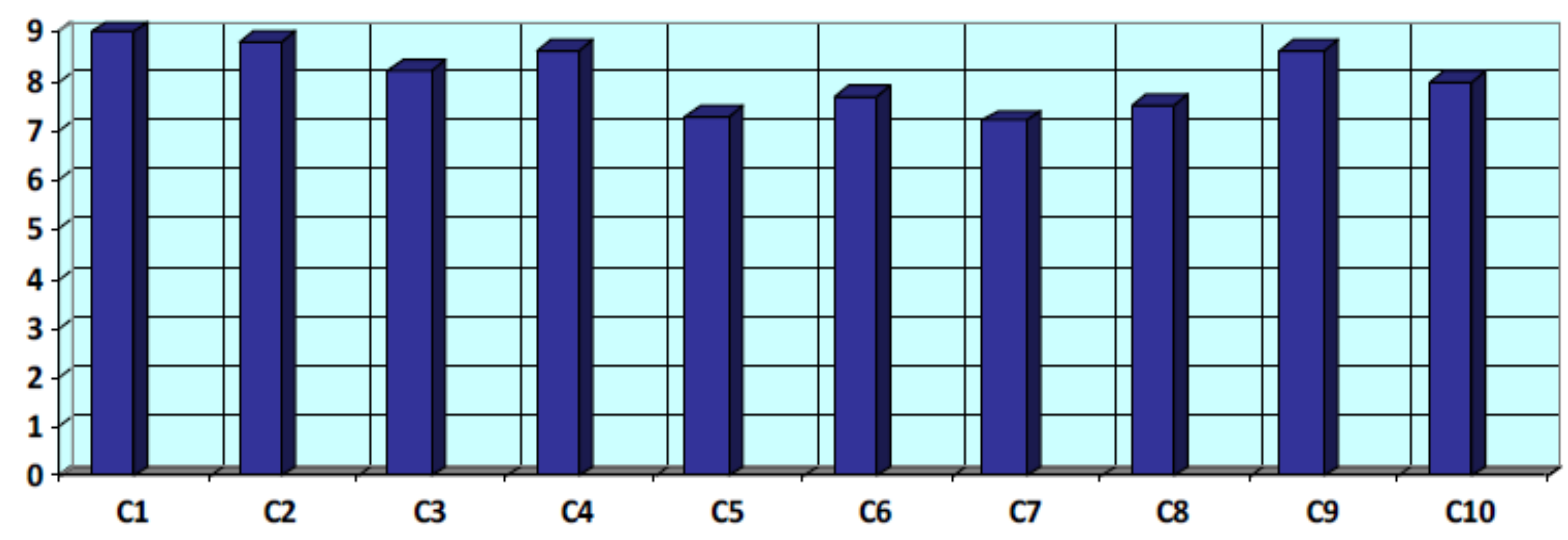

Fig2. Graphical representation of the $\mathrm{pH}$

\subsection{Moisture Contents}

The texture of soil based on water holding capacity was found to be Loam sandy. In the study of different location of crop land area of Chitrakoot we have reported minimum moisture content in sample C5 (1.06) and maximum value found in sample C6 (3.25). Moisture contents results of the all samples are given in table-2 and shown in fig. 3 . 


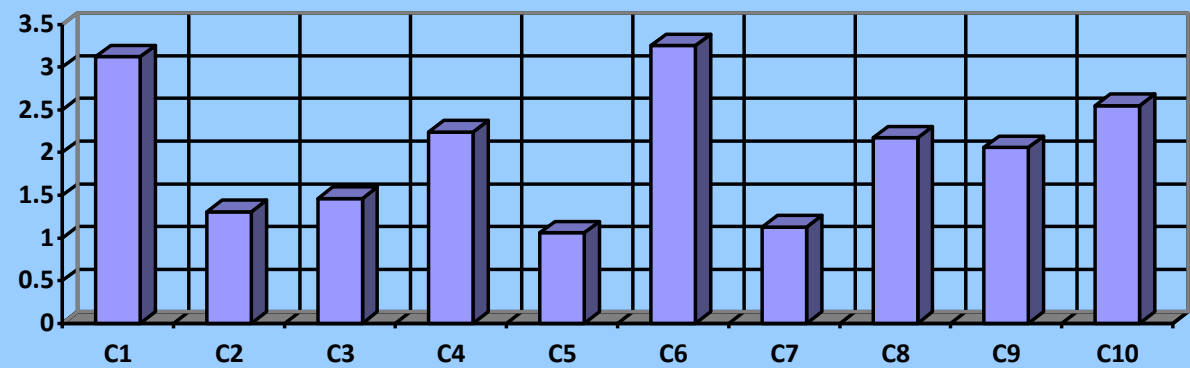

Fig3. Graphical representation of the moisture content

\subsection{Nitrogen $(\mathbf{N})$}

Nitrogen is the most important fertilizer element. Plants respond quickly to application of nitrogen salts. This element encourages above ground vegetative growth and gives a deep green colour to the leaves. In the present study the sample C4 showed $34.13 \mathrm{mg} / \mathrm{kg}$ of nitrogen whereas sample C7 showed less percentage of nitrogen $4.30 \mathrm{mg} / \mathrm{kg}$. Nitrogen results of the all samples are given in table2 and shown in fig.4.

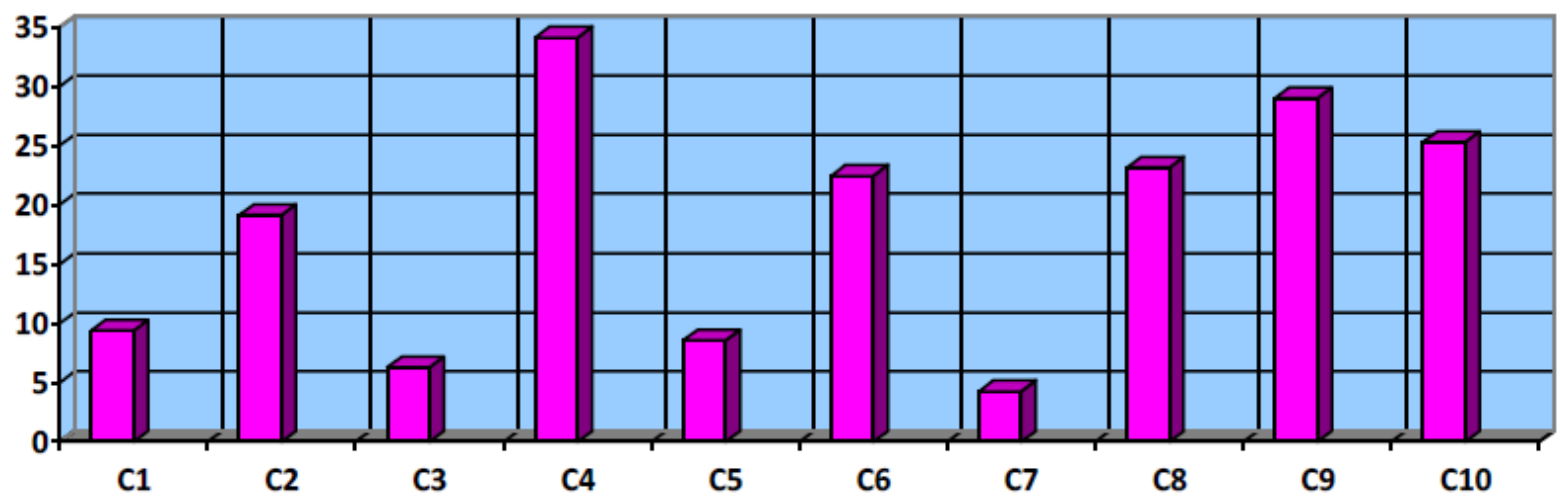

Fig4. Graphical representation of the temperature

\subsection{Phosphorus (P)}

Phosphorus is a part of every living cell in crop. The every activity of plant such as growth, respiration and reproduction depends upon phosphorus levels of the soil in which the crop grows. In the present study the amount of available phosphorus at C6 and C5 are 3.07 and $1.14 \mathrm{mg} / \mathrm{kg}$, whereas at $\mathrm{C} 3$ there is reduction in available phosphorous content i.e. $0.28 \mathrm{mg} / \mathrm{kg}$. Phosphorus results of the all samples are given in table-2 and shown in fig.5.

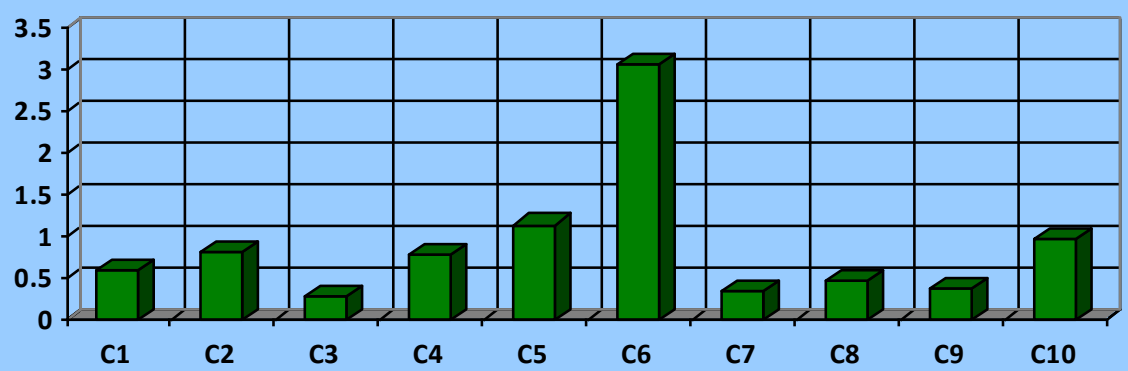

Fig5. Graphical representation of the temperature

\subsection{Potassium (K)}

Potassium is not an integral part of any major plant component but it plays a key role in a vast array of physiological process vital to plant growth from protein synthesis to maintenance of plant - water balance. In the present study sample C7 showed $27 \mathrm{mg} / \mathrm{kg}$ of K whereas sample C1 showed $56 \mathrm{mg} / \mathrm{kg}$. Potassium results of the all samples are given in table- 2 and shown in fig.6. 


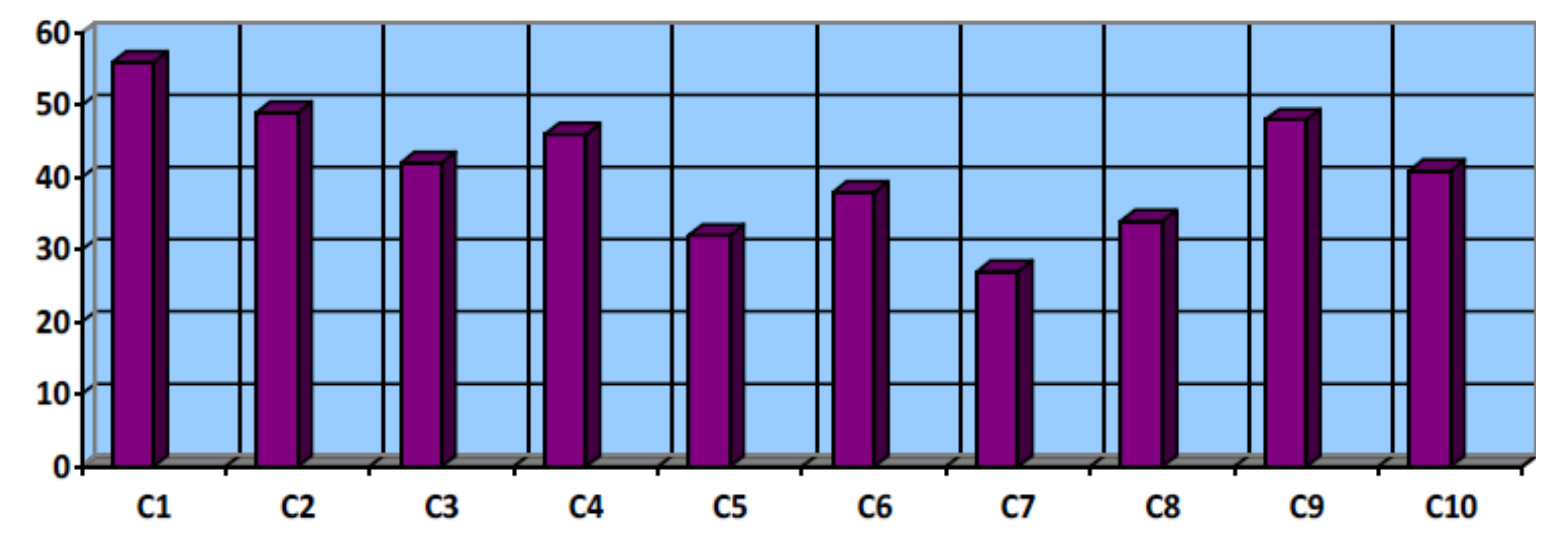

Fig6. Graphical representation of the temperature

\section{DISCUSSION}

In the Present Study soil Samples were collected from various locations of crop land area of Chitrakoot region and all the results of Physico-Chemical analysis are shown in Table-2. The $\mathrm{pH}$ of the soil taken from the depth of $15 \mathrm{~cm}$ at different sites ranged from 7.2 to 9.0 which indicate that the soil is alkaline .Pandeeswari, N. et al, (2012) ${ }^{[14]}$, reported ranges of $\mathrm{pH}$ of soil were 5-8. Soil $\mathrm{pH}$ is an important consideration for farmers and gardeners for several reasons, including the fact that many plants and soil life forms prefer either alkaline or acidic conditions or the $\mathrm{pH}$ can affect the availability of nutrients in the soil

Moisture content of samples were found 1.06 to $0.28 \%$.In Chitrkoot region we have analyzed minimum moisture content in sample C5(1.06) and maximum value found in sample C6(3.25).

Jain Parul et al, (2014) ${ }^{[15]}$ suggested phosphorus $(\mathrm{P})$ is necessary for maintaining a balance between the other plant nutrients and ensuring the normal growth of the crop. Phosphorus is a part of every living cell in crop. The every activity of plant such as growth, respiration and reproduction depends upon phosphorus levels of the soil in which the crop grows. In the present study the amount of available phosphorus at $\mathrm{C} 6$ and $\mathrm{C} 5$ are 3.07 and $1.14 \mathrm{mg} / \mathrm{kg}$, whereas at $\mathrm{C} 3$ the phosphorous content is very less amount i.e. $0.28 \mathrm{mg} / \mathrm{kg}$.

Nitrogen contents in Soil of Chitrakoot region were analysed and reported. Its concentration ranged between 4.30 to $34.13 \mathrm{mg} / \mathrm{kg}$. Tripathi et al. $2014^{[16]}$ studied concentration of $\mathrm{Cr}, \mathrm{Pb}, \mathrm{Cd}, \mathrm{Ni}, \mathrm{Cu}$ and Fe in soil of Umaria District, Vindhya Platue, India and reported N, P, K are found to be 8.86 to 41.50 $\mathrm{mg} / \mathrm{kg}$. Nitrogen is the most important fertilizer element. Plants respond quickly to application of nitrogen salts. This element encourages above ground vegetative growth and gives a deep green colour to the leaves. Plant roots take up nitrogen in the form of $\mathrm{NO}_{3}$ and $\mathrm{NH}_{4}$. The sample station $\mathrm{C} 4$ Showed maximum nitrogen concentration $34.13 \mathrm{mg} / \mathrm{kg}$ and Sample station C7 showed minimum concentration of nitrogen $4.30 \mathrm{mg} / \mathrm{kg}$ (Table 2)

The Potassium values were ranging between $27 \mathrm{mg} / \mathrm{kg}$ to $56 \mathrm{mg} / \mathrm{kg}$. In the Chitrakoot region, the lightest Potassium was found in (C7) as Show in (Table 2). Dwivedi A.P., et al, 2013, ${ }^{[17]}$ carried out assessment of soil and ground water quality in rewa District of Vindhya platue and reported the potassium content ranged from 2.10 to $55.0 \mathrm{mg} / \mathrm{kg}$. Potassium is not an integral part of any major plant component but it plays a key role in a vast array of physiological process vital to plant growth from protein synthesis to maintenance of plant - water balance. All the values of $\mathrm{N}, \mathrm{P}$, and $\mathrm{K}$ were below the recommended level of SQGL Value ${ }^{[18]}$.

\section{CONClusion}

The present study of physicochemical parameters is important to agricultural Chemists for crop growth and soil management. A physico-chemical studies of soil samples from ten sampling station of crop land area of Chitrakoot region, All the Soil samples were analyzed parameters like pH-(7.2 to 9.0), Temperature-(26 to $\left.28^{\circ} \mathrm{C}\right)$, Moisture content-(1.06 to $\left.3.25 \%\right), \mathrm{N}-(4.30$ to $34.13 \mathrm{mg} / \mathrm{kg}), \mathrm{P}-(0.28$ to $3.07 \mathrm{mg} / \mathrm{kg}$ ), and $\mathrm{K}-(27$ to $56 \mathrm{mg} / \mathrm{kg}$ ), are in normal range. These studies give information about nature of soil, present nutrient in soil; according to this information farmer arrange the amount fertilizers and nutrients needed to soil for increase the crop production. 


\section{REFERENCES}

[1] Al-Omran, A.M., A.S.Sheta, A.M. Falatah \& Al-Harbi, A.R.(2005), Effect of Drip Irrigation on Squash (Cucurbita Pepo) Yield and Water use Efficiency in Sandy Calcareous Soils Amended with Clay Deposi, Agricultural Water Management., ,73: 43-55.

[2] M.I. Saleh and O. Kiyoshi, (2006), Improvement of Crop Yield, Soil Moisture Distribution and Water use Efficiency in Sandy Soils by Clay Application. In: Tenth International Water Technology Conference, IWTC10 Alexandria, Egypt, 797-811.

[3] Paudel, S. and Sah, J.P. (2003), Physio-chemical Characteristics of Soil in Tropical Sal (Shorea robusta Gaertn.) Forests in Eastern Nepal. Himalayan J. Sci. 1(2): 107-110.

[4] Ahire, D.V., Chaudhari, P.R., Ahire, V.D. and Patil, A.A. (2013), Correlations of Electrical Conductivity and Dielectric Constant with Physico-Chemical Properties of Black Soils. Int. J. Scientific and Res. Publications. 3(2): 1-16.

[5] S.Sumithra, Ankalaiah, C., Rao, D. and Yamuna, R.T. (2013), A Case Study on Physico chemical Characteristics of Soil Around Industrial and Agricultural Area of Yerraguntla, Kadapa District, A. P, India. Int. J. Geo. Earth and Environ. Sci. 3(2): 28-34.

[6] Jain Parul and Singh Dharmendra, (2013), Analysis the Physico-chemical and Microbial Diversity of Different Variety of Soil Collected from Madhya Pradesh India. Scholar Journal of Agricultural Science, 4 (2): 113-118.

[7] Wagh G.S. et al, (2013), Physico-chemical Analysis of Soil from Eastern Part of Pune City. Universal journal of environmental research and technology, 3 (1): 93-99.

[8] Pujar, K.G., Hiremath, S.C., Pujar, A.S., Pujeri, U.S. and Yadawe, M.S. (2012), Analysis of Physico-Chemical and Heavy Metal Concentration in Soil of Bijapur Taluka, Karnataka. Sci. Revs. Chem. Commun. 2(1): 76-79.

[9] Adhikari, K., Guadagnini, A., Toth, G. and Hermann, T. (2009), Geo-statistical Analysis of Surface Soil Texture from Zala County in Western Hungary. International Symposium on Environment, Energy and Water in Nepal: Recent Researches and Direction for Future.

[10] Piper C.S., A Laboratory Manual of Methods for the Examination of Soil and the Determination of the Inorganic Constituents of Plant, Original Edition-1992. Printed in India. Scientific publishers Jodhpur (Raj.) India.

[11] Sharma V.K, Environmental Chemistry, Goel publishing House, Meerut, (2000).

[12] Jaiswal,P.C.,soil plant and water analysis (2006), $2^{\text {nd }}$ Edition kalyani publisher Ludhiyana india.

[13] APHA (American Public Health Association), Standard Methods for the Examination of Water and Waste Water. $19^{\text {th }}$ Ed. (1995), American Public Helth Association, Washington,DC.

[14] Pandeeswari, N. and S. Kalaiarasu, (2012), Studies On The Physico-Chemical Properties Of The Soil Samples Collected From Different Locations Of Tsunami Affected Soils Of Cuddalore District Of Tamil Nadu. Int. J. Current Res. 4(7):143-145.

[15] Jain Parul and Singh Dharmendra, (2014), Analysis the Physic-chemical and Microbial Diversity of Different Variety of Soil collected from Madhya Pradesh India. Scholar Journal of Agricultural Science, 4 (2): 103-108.

[16] Indra Prasad Tripathi, M. Suresh Kumar and Arvind Prasad Dwivedi, (2014),Concentration of $\mathrm{Cr}, \mathrm{Cd}, \mathrm{Ni}, \mathrm{Cu}$ and $\mathrm{Fe}$ in Soil of Umaria District, Vindhya Platue, India, International Journal of research Analysis and Evaluation, .5(52):28- 32.

[17] A.P. Dwivedi, I.P. Tripathi and M. Suresh Kumar, (2013), Assessment of Soil and Ground Water Quality in Rewa District of Vindhya Plateau (India), Journal Environment Sciences and Engg.,5 (1): 51-54 .

[18] P.K. Govil, J.E. Sorlie, N.N. Murthy, D. Sujatha, D. Reddy G.L.N., Rodolph-lund kim, Krishna, A.K. and K. Rama Mohan, (2008), Soil Contamination of Heavy Metals in the Katedan Industrial development Area, Hyderabad, India; Journal of Environment Assess.140:313-323. 